\title{
GAMBARAN SANITASI PEMUKIMAN DI DESA ROWOREJO KECAMATAN NEGERI KATON KABUPATEN PESAWARAN TAHUN 2020
}

\author{
Dian Septi Melani ${ }^{1 *}$, Mei Ahyanti ${ }^{2}$, Daria Ginting ${ }^{3}$ \\ 1,2,3 Poltekkes Kemenkes Tanjungkarang, Lampung, Indonesia
}

\section{Artikel Info :}

Received 21 April 2021

Accepted 16 Agustus 2021

Available online 31 Agustus 2021

Editor: Amrul Hasan

Keyword :

House, sanitation facilities, behavior

Kata Kunci :

Rumah sehat, sarana sanitasi, perilaku

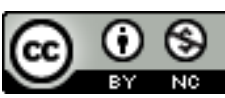

Ruwa Jurai: Jurnal

Kesehatan Lingkungan is

licensed under a Creative

Commons Attribution-

NonCommercial 4.0 International License.

\begin{abstract}
A b stract
An unhealthy environment can lead to environmental-based disease transmission. Based on the preliminary survey, many houses still do not meet health requirements, such as having no ceiling, closed sewerage, and no latrine. This study aims to determine the description of residential sanitation, including the components of the house, the components of sanitation facilities, and the occupants' behavior. This research is descriptive with the survey method. The population is all houses in Roworejo Village, as many as 1,244 houses. Data collection is done by visiting people's homes, conducting an assessment using a checklist guide. Interviews were conducted to support the required data. The data that has been collected is scored, processed with a computer program, and presented in tabular form. The results of the study found that the majority of the sanitation components had met the requirements. However, there are still physical components of the house (30\%), components of sanitation facilities (34\%), and unhealthy behavior of residents (30\%). Increasing public knowledge is an action that must be taken in order to change public health behavior.
\end{abstract}

Lingkungan yang tidak sehat dapat menimbulkan penularan penyakit berbasis lingkungan. Berdasarkan survei pendahuluan, masih banyak rumah yang belum memenuhi syarat kesehatan, seperti tidak memiliki langit-langit, saluran pembuangan air limbah tertutup, tidak memiliki jamban. Penelitian bertujuan untuk mengetahui gambaran sanitasi pemukiman meliputi komponen rumah, komponen sarana sanitasi dan perilaku penghuni. enelitian bersifat deskriptif dengan metode survei. Populasi adalah seluruh rumah yang ada di Desa Roworejo, sebanyak 1.244 rumah. Pengumpulan data dilakukan dengan mendatangi rumah-rumah warga, melakukan penilaian menggunakan panduan checklist. Wawancara dilakukan untuk mendukung data-data yang diperlukan. Data yang telah terkumpul diberi score, diolah dengan program komputer dan disajikan dalam bentuk tabel. Hasil penelitian mendapatkan mayoritas komponen sanitasi telah memenuhi syarat. Namun masih ditemukan komponen fisik rumah (30\%), komponen sarana sanitasi (34\%) dan perilaku penghuni yang tidak sehat (30\%). Meningkatkan pengetahuan masyarakat menjadi tindakan yang harus dilakukan agar terjadi perubahan perilaku kesehatan masyarakat.
${ }^{*}$ Corresponding author : Dian Septi Melani

Jalan Soekarno-Hatta No 6, Bandar Lampung, Lampung, Indonesia

Email: septimelani11@gmail.com

\section{PENDAHULUAN}

HL Blum menyatakan bahwa faktor-faktor yang mempengaruhi derajat kesehatan adalah kondisi lingkungan, perilaku, pelayanan kesehatan dan keturunan. Hal ini diperlukan sebagai syarat untuk mencapai derajat kesehatan yang diinginkan. Lingkungan memiliki pengaruh yang paling besar terhadap derajat kesehatan disusul oleh perilaku (Eliana \& Sumiati, 2016). Lingkungan yang tidak memenuhi syarat terkait erat dengan penyakit berbasis lingkungan, seperti Infeksi Saluran Pernafasan (ISPA), Tuberkulosis, Pneumonia, 
diare, kecacingan, penyakit kulit, serta penyakit yang ditularkan melalui vektor seperti demam berdarah, malaria, dan filariasis (May Ahyanti, Rosita, \& Yushananta, 2020; Suwita, Syafri, \& Fahri, 2019; Yushananta, Ahyanti, \& Hasan, 2018; Yushananta, Setiawan, \& Tugiyono, 2020; Yushananta \& Usman, 2018).

Kondisi lingkungan pemukiman yang buruk terlihat dari rendahnya masyarakat yang dapat menjangkau pelayanan air bersih, pembuangan kotoran, pembuangan sampah, kondisi rumah yang tidak layak dan pembuangan limbah cair yang tidak sehat (Agungnisa, 2019; Mei Ahyanti \& Duarsa, 2013; Cora, B, \& Adam, 2020; Mahendra \& Farapti, 2018; Puteri, 2011; Yasin, Mumpuningtyas, \& Faizin, 2018). Perilaku manusia selain dapat berdampak terhadap kesehatan juga dapat mempengaruhi kualitas lingkungan pemukiman. Banyak masyarakat yang masih memiliki perilaku hidup yang tidak sehat, seperti buang air besar di kebun atau di sungai yang airnya kotor, mencuci di sungai yang airnya kotor serta membuang sampah sebarangan (Widiastuti, 2019).

Berdasarkan data Dinas Kesehatan Kabupaten Pesawaran (Dinas Kesehatan Kabupaten Pesawaran, 2017), jumlah rumah sehat di Kabupaten Pesawaran sebanyak 73.409 rumah (77,43\%), dan sisanya masuk dalam kategori tidak sehat (94.809 rumah). Rumah tidak sehat memiliki potensi penularan penyakit berbasis lingkungan seperti pneumonia tau penyakit pernafasan, diare dan penyakit kulit. Desa Roworejo merupakan salah satu desa yang berada di Kecamatan Negeri Katon, Kabupaten Pesawaran. Kasus pneumonia di Desa Roworejo menduduki peringkat ketiga dari 12 desa yang ada di Kabupaten tersebut setelah Desa Bunut dan Desa Kedondong (Dinas Kesehatan Kabupaten Pesawaran, 2017). Berdasarkan survei awal, masih banyak bangunan rumah yang belum memiliki langit-langit, sebagian besar rumah memiliki saluran pembuangan air limbah yang tidak tertutup dan beberapa rumah belum memiliki jamban serta hampir semua masyarakat membakar sampah di halaman rumah. Berdasarkan uraian diatas, maka mendorong penulis untuk melakukan penelitian tentang gambaran sanitasi pemukiman.

\section{METODE}

Penelitian ini adalah penelitian deskriptif dengan metode survei, untuk mengetahui menggambarkan sanitasi pemukiman di Desa Roworejo Kecamatan Negeri Katon Kabupaten Pesawanan. Penelitian dilaksanakan pada Bulan Februari 2020 dengan populasi seluruh rumah di Desa Roworejo Kecamatan Negeri Katon Kabupaten Pesawaran. Sampel dalam penelitian ini diambil seluruh anggota populasi sebagai responden. Sampel berjumlah 1244 KK, dimana setiap KK menempati 1 rumah.

Pengumpulan data dilakukan dengan mendatangi rumah satu per satu kemudian melakukan pengamatan menggunakan checklist terhadap komponen sanitasi pemukiman dan wawancara menggunakan kuesioner untuk mendapatkan informasi-informasi pendukung. Data yang terkumpul diolah menggunakan bantuan program komputer dan disajikan dalam bentuk tabel.

Komponen fisik rumah yang di nilai adalah langit-langit, dinding, lantai, jendela, ventilasi, lubang asap dapur dan pencahayaan. Penilaian komponen sarana sanitasi dilakukan terhadap sarana air bersih, sarana pembuangan kotoran, sarana air limbah (SPAL), pembuangan sampah, kondisi halaman, keberadaan binatang penular, dan keberadaan kandang hewan peliharaan. Sedangkan penilaian perilaku dilakukan terhadap kebiasaan membuka jendela kamar, membuka jendela keluarga, membersihkan rumah dan halaman, membuang tinja balita, membuang sampah, kebiasaan merokok dan penggunaan obat nyamuk.

Pembobotan terhadap setiap komponen mengacu pada Kementerian Kesehatan RI (1999) tentang persyaratan rumah sehat. Instrumen pengukuran menggunakan instrument yang disusun oleh Kementerian Kesehatan RI (2007) yang diinterpretasikan terhadap bobot komponen fisik rumah sebesar 31, bobot sarana sanitasi 25 dan bobot perilaku 44. Setiap item pengamatan memiliki nilai. Hasil penilaian diperoleh dengan mengalikan nilai dengan bobot. Komponen fisik dan sarana sanitasi dinyatakan memenuhi syarat apabila memiliki nilai $\geq 70 \%$ dari nilai maksimum. Demikian juga dengan perilaku, dikatakan perilaku sehat memiliki nilai $\geq 70 \%$ dari nilai maksimum. 


\section{HASIL}

Tabel 1 menunjukkan gambaran komponen fisik rumah masyarakat Desa Roworejo, meliputi langit-langit, dinding, lantai, jendela, ventilasi, lubang asap dapur, dan pencahayaan. Lebih dari separuh rumah $(55,71 \%)$ tidak memiliki langitlangit. Sebagian besar rumah $(84,24 \%)$ telah memiliki dinding permanen, sisanya dari anyaman bambu $(1,77 \%)$, dan semi permanen (13,99\%).

Walaupun mayoritas $(82,96 \%)$ lantai rumah telah kedap air, namun masih ditemukan rumah dengan lantai tanah (2,25\%). Rumah yang tidak memiliki jendela kamar tidur sebanyak 2,17\%, sedangkan rumah yang tidak memiliki jendela ruang keluarga sebanyak 2,09\%.

Sebanyak 56 rumah (4,5\%) tidak memiliki ventilasi, dan 647 rumah $(52,25 \%)$ memiliki ventilasi yang luasnya kurang dari $10 \%$ dari luas lantai. Sebagian besar rumah terdapat lubang asap dapur yang luasnya $<10 \%$ luas lantai dapur (52,01\%), 20\% rumah tidak memiliki lubang asap dapur. Sedangkan pada komponen pencahayaan, ditemukan $3,23 \%$ rumah yang kurang terang dan $1,35 \%$ tidak terang.

Tabel 1. Hasil Pemeriksaan komponen fisik rumah

\begin{tabular}{|c|c|c|c|c|}
\hline $\begin{array}{l}\text { Komponen yang } \\
\text { diperiksa }\end{array}$ & Nilai & Kriteria & $\mathrm{n}$ & $\%$ \\
\hline \multirow[t]{3}{*}{ Langit-langit } & 0 & Tidak ada & 693 & 55,71 \\
\hline & 1 & Ada, kotor, sulit dibersihkan dan rawan kecelakaan & 141 & 11,33 \\
\hline & 2 & Ada, bersih dan tidak rawan kecelakaan & 410 & 32,96 \\
\hline \multirow[t]{3}{*}{ Dinding } & 1 & Bukan tembok (anyaman bambu) & 22 & 1,77 \\
\hline & 2 & $\begin{array}{l}\text { Semi permanen/setengah tembok/pasangan bata/bata } \\
\text { tidak diplester/papan tidak kedap air }\end{array}$ & 174 & 13,99 \\
\hline & 3 & $\begin{array}{l}\text { Permanen/tembok/pasangan bata diplester/papan kedap } \\
\text { air }\end{array}$ & 1048 & 84,24 \\
\hline \multirow[t]{3}{*}{ Lantai } & 0 & Tanah & 28 & 2,25 \\
\hline & 1 & $\begin{array}{l}\text { Papan/anyaman bambu dekat dengan tanah/plesteran } \\
\text { retak dan berdebu }\end{array}$ & 184 & 14,79 \\
\hline & 2 & Diplester/ubin/keramik/papan (rumah panggung) & 1032 & 82,96 \\
\hline Jendela kamar & 0 & Tidak ada & 27 & 2,17 \\
\hline tidur & 1 & Ada & 1217 & 97,83 \\
\hline Jendela ruang & 0 & Tidak ada & 26 & 2,09 \\
\hline keluarga & 1 & Ada & 1218 & 97,91 \\
\hline \multirow{4}{*}{ Ventilasi } & 0 & Tidak ada & 56 & 4,50 \\
\hline & 1 & Tiada ada (buatan/AC) & 12 & 0,96 \\
\hline & 2 & Ada, luas ventilasi permanen $<10 \%$ luas lantai & 650 & 52,25 \\
\hline & 3 & Ada, luas ventilasi permanen $\geq 10 \%$ luas lantai & 526 & 42,28 \\
\hline Lubang asap & 0 & Tidak ada & 242 & 19,45 \\
\hline \multirow[t]{2}{*}{ dapur } & 1 & Ada, lubang ventilasi dapur $<10 \%$ luas lantai dapur & 647 & 52,01 \\
\hline & 2 & Ada, lubang ventilasi dapur $\geq 10 \%$ luas lantai dapur & 355 & 28,54 \\
\hline \multirow[t]{3}{*}{ Pencahayaan } & 0 & Tidak terang, tidak dapat untuk membaca & 13 & 1,35 \\
\hline & 1 & Kurang terang, kurang jelas untuk membaca & 31 & 3,23 \\
\hline & 2 & $\begin{array}{l}\text { Terang dan tidak silau dapat untuk membaca dengan } \\
\text { normal }\end{array}$ & 916 & 95,42 \\
\hline
\end{tabular}

Hasil pemeriksaan komponen sarana sanitasi disajikan pada Tabel 2. Sebagian besar rumah $(81,67 \%)$ telah memiliki sarana air bersih yang memenuhi syarat kesehatan. Namun masih terdapat $8,84 \%$ rumah tangga yang mengkonsumsi air yang tidak memenuhi syarat kesehatan.

Mayoritas rumah telah memiliki jamban leher angsa memiliki tutup dan terdapat septic tank $(87,46)$, sedangkan rumah yang tidak memiliki jamban sebanyak 15 rumah (1,21\%). Hampir 
separuh rumah $(48,31 \%)$ mengalirkan limbahnya dengan saluran terbuka, bahkan tidak memiliki SPAL (1,37\%). Namun, sebanyak 5,14\% rumah telah mengalirkan limbahnya dengan saluran tertutup, dan sebanyak 39,55\% memiliki SPAL dengan peresapan.
Masih terdapat rumah yang tidak memiliki sarana pembuangan sampah (25,16\%), ditemukan jentik nyamuk (10,93\%), terdapat tikus (41,08\%). Pekarangan yang kotor tidak dimanfaatkan sebanyak $40,76 \%$ dan $8,6 \%$ rumah memiliki kandang yang tidak terpisah dari rumah.

Tabel 2. Hasil Pemeriksaan Komponen Sarana Sanitasi

\begin{tabular}{|c|c|c|c|c|}
\hline $\begin{array}{l}\text { Komponen yang } \\
\text { diperiksa }\end{array}$ & Nilai & Kriteria & $\mathrm{n}$ & $\%$ \\
\hline \multirow[t]{4}{*}{ Sarana air bersih } & 1 & $\begin{array}{l}\text { Ada, bukan milik sendiri, tidak memenuhi syarat } \\
\text { kesehatan }\end{array}$ & 36 & 2,89 \\
\hline & 2 & Ada, milik sendiri, tidak memenuhi syarat kesehatan & 74 & 5,95 \\
\hline & 3 & Ada, bukan milik sendiri, memenuhi syarat kesehatan & 118 & 9,49 \\
\hline & 4 & Ada, milik sendiri, memenuhi syarat kesehatan & 1016 & 81,67 \\
\hline Sarana & 0 & Tidak ada & 15 & 1,21 \\
\hline \multirow[t]{4}{*}{$\begin{array}{l}\text { Pembuangan } \\
\text { Kotoran (Jamban) }\end{array}$} & 1 & $\begin{array}{l}\text { Ada, bukan leher angsa, tidak ada tutup, disalurkan ke } \\
\text { sungai/kolam }\end{array}$ & 12 & 0,96 \\
\hline & 2 & $\begin{array}{l}\text { Ada, bukan leher angsa, ada tutup, disalurkan ke } \\
\text { sungai/kolam }\end{array}$ & 18 & 1,45 \\
\hline & 3 & Ada, bukan leher angsa, ada tutup, septic tank & 111 & 8,92 \\
\hline & 4 & Ada, leher angsa, ada tutup, septic tank & 1088 & 87,46 \\
\hline \multirow{5}{*}{$\begin{array}{l}\text { Sarana } \\
\text { pembuangan air } \\
\text { limbah (SPAL) }\end{array}$} & 0 & $\begin{array}{l}\text { Tidak ada, sehingga tergenang tidak teratur di halaman } \\
\text { rumah }\end{array}$ & 17 & 1,37 \\
\hline & 1 & $\begin{array}{l}\text { Ada, diresapkan tetapi mencemari sumber air (jarak } \\
\text { dengan sumber air }<10 \mathrm{~m} \text { ) }\end{array}$ & 70 & 5,63 \\
\hline & 2 & Ada, dialirkan ke selokan terbuka & 601 & 48,31 \\
\hline & 3 & $\begin{array}{l}\text { Ada, diresapkan tidak mencemari sumber air (jarak } \\
\text { dengan sumber air } \geq 10 \mathrm{~m} \text { ) }\end{array}$ & 492 & 39,55 \\
\hline & 4 & $\begin{array}{l}\text { Ada, dialirkan ke selokan tertutup (saluran kota) untuk } \\
\text { diolah }\end{array}$ & 64 & 5,14 \\
\hline \multirow{4}{*}{$\begin{array}{l}\text { Sarana } \\
\text { pembuangan } \\
\text { Sampah }\end{array}$} & 0 & Tidak ada & 313 & 25,16 \\
\hline & 1 & Ada, tidak kedap air, tidak tertutup & 386 & 31,03 \\
\hline & 1 & Ada, kedap air, tidak tertutup & 437 & 35,13 \\
\hline & 2 & Ada, kedap air, tertutup & 108 & 8,68 \\
\hline \multirow{4}{*}{$\begin{array}{l}\text { Binatang penular } \\
\text { penyakit }\end{array}$} & 0 & Ada jentik nyamuk dan tikus & 136 & 10,93 \\
\hline & 1 & Tidak ada jentik, ada tikus & 511 & 41,08 \\
\hline & 2 & Ada jentik nyamuk, tidak ada tikus & 137 & 11,01 \\
\hline & 3 & Tidak ada jentik nyamuk dan tidak ada tikus & 460 & 36,98 \\
\hline \multirow[t]{3}{*}{ Pekarangan } & 0 & Kotor, tidak dimanfaatkan & 507 & 40,76 \\
\hline & 1 & Bersih, tidak dimanfaatkan & 107 & 8,60 \\
\hline & 2 & Bersih, dimanfaatkan & 630 & 50,64 \\
\hline \multirow{3}{*}{$\begin{array}{l}\text { Kandang hewan } \\
\text { peliharaan }\end{array}$} & 0 & Tidak ada & 507 & 40,76 \\
\hline & 1 & Ada, tidak terpisah dengan rumah & 107 & 8,60 \\
\hline & 2 & Ada, terpisah dengan rumah & 630 & 50,64 \\
\hline
\end{tabular}

Pada Tabel 3 terlihat bahwa sebagian besar rumah tangga memiliki perilaku selalu membuka jendela kamar $(65,19 \%)$ dan jendela ruang keluarga (46,22\%). Namun masih terdapat rumah yang tidak membuka jendela kamar $(4,02 \%)$ dan ruang keluarga $(7,07 \%)$.

Mayoritas halaman rumah dibersihkan setiap hari $(84,24 \%)$, buang air besar dan membuang tinja balita ke jamban (86,33\%), membuang 
sampah di tempat sampah (73,87\%). Hasil penelitian juga mendapatkan sebanyak 53,62\%

dalam rumah dan menggunakan obat nyamuk rumah tangga memiliki kebiasaan merokok di bakar (11,50\%).

Tabel 3. Hasil Pemeriksaan Komponen Perilaku Penghuni

\begin{tabular}{lllll}
\hline $\begin{array}{l}\text { Komponen yang } \\
\text { diperiksa }\end{array}$ & Nilai & Kriteria & $\mathrm{n}$ & $\%$ \\
\hline Membuka jendela & 0 & Tidak pernah dibuka & 50 & 4,02 \\
kamar tidur & 1 & Kadang-kadang & 383 & 30,79 \\
& 2 & Dibuka setiap hari & 811 & 65,19 \\
Membuka jendela & 0 & Tidak pernah dibuka & 88 & 7,07 \\
ruang keluarga & 1 & Kadang-kadang & 581 & 46,70 \\
& 2 & Dibuka setiap hari & 575 & 46,22 \\
Membersihkan & 0 & Tidak pernah & 7 & 0,56 \\
rumah dan & 1 & Kadang-kadang & 189 & 15,19 \\
halaman & 2 & Dibersihkan setiap hari & 1048 & 84,24 \\
Membuang tinja & 0 & Ke sungai/kebun/kolam/sebarang tempat & 61 & 4,90 \\
balita ke jamban & 1 & Kadang-kadang ke jamban & 109 & 8,76 \\
& 2 & Ke jamban & 1074 & 86,33 \\
Membuang & 0 & Ke sungai/kebun/kolam/sebarang tempat & 255 & 20,50 \\
sampah pd & 1 & Kadang-kadang ke tempat sampah & 70 & 5,63 \\
tempat sampah & 2 & Dibuang ke tempat sampah & 919 & 73,87 \\
Kebiasaan & 0 & Ada anggota keluarga yang merokok di dalam rumah & 667 & 53,62 \\
merokok & 1 & Ada anggota keluarga yang merokok, di teras rumah & 219 & 17,60 \\
& 2 & Tidak ada yang merokok & 358 & 28,78 \\
Penggunaan obat & 0 & Menggunakan obat nyamuk bakar & 143 & 11,50 \\
nyamuk & 1 & Kadang-kadang menggunakan obat nyamuk & 235 & 18,89 \\
& 2 & Menggunakan kelambu & 866 & 69,61 \\
\hline
\end{tabular}

Tabel 4 merupakan pengelompokan komponen sanitasi pemukiman setelah dilakukan pembobotan. Hasil penelitian mendapatkan sebanyak 69,94\% komponen fisik rumah telah memenuhi persyaratan kesehatan.
Berdasarkan komponen sarana sanitasi, sebagian besar (66,16\%) telah memenuhi syarat kesehatan. Demikian pula pada komponen perilaku, sebagian besar $(69,86 \%)$ telah memiliki perilaku yang baik.

Tabel 4. Distribusi responden berdasarkan komponen sanitasi pemukiman

\begin{tabular}{lcc}
\hline Komponen Sanitasi Pemukiman & $\mathrm{n}$ & $\%$ \\
\hline Komponen Fisik Rumah & & \\
$\quad$ Tidak memenuhi syarat & 374 & 30,06 \\
$\quad$ Memenuhi syarat & 870 & 69,94 \\
Komponen Sarana Sanitasi & & \\
$\quad$ Tidak memenuhi syarat & 421 & 33,84 \\
$\quad$ Memenuhi syarat & 823 & 66,16 \\
Komponen Perilaku Penghuni & & \\
$\quad$ Tidak sehat & 375 & 30,14 \\
$\quad$ Sehat & 869 & 69,86 \\
\hline
\end{tabular}




\section{PEMBAHASAN}

\section{Komponen Fisik Rumah}

Komponen fisik rumah merupakan suatu unsur penyusun rumah secara fisik, sesuai kebutuhan ruang dan aktivitas setiap penghuninya. Hasil penelitian mendapatkan mayoritas $(69,94 \%)$ rumah di Desa Roworejo telah memenuhi syarat komponen fisik rumah (Tabel 1). Pada kelompok yang tidak memenuhi syarat (30,06\%), komponen yang belum memenuhi syarat meliputi langit-langit, ventilasi dan lubang asap dapur.

Di Desa Roworejo terdapat 55,71\% rumah tidak memiliki langit-langit, dan $11,33 \%$ telah memiliki langit- langit namun kotor sulit dibersihkan. Menurut (Kementerian Kesehatan RI, 1999), sebuah rumah sebaiknya memiliki langit-langit yang bersih dan tidak rawan kecelakaan. Fungsi utama langit-langit adalah untuk menjaga suhu dan kelembaban di dalam rumah akibat sinar matahari yang menyinari atap rumah. Udara panas akan ditahan oleh langitlangit, sehingga tidak langsung mengalir ke dalam rumah. Selain itu, langit- langit juga berfungsi menahan debu dan kotoran. Rumah yang tidak memiliki langit-langit, memungkinkan masuknya debu ke dalam rumah dan akan mengganggu penghuni rumah dan berakibat pada sakit infeksi saluran pernafasan (Mahendra \& Farapti, 2018; Syahidi, Gayatri, \& Bantas, 2016). Langit-langit harus mudah dibersihkan dan tidak rawan kecelakaan agar menjamin kesehatan dan keselamatan penghuninya (Kartiningrum, 2013).

Ventilasi berfungsi untuk menjaga aliran udara di dalam rumah tetap segar. Rumah dengan ventilasi yang tidak memenuhi syarat akan meningkatkan kadar Carbon dioksida $\left(\mathrm{CO}_{2}\right)$ yang bersifat racun, meningkatnya kelembaban udara dalam ruangan sehingga membentuk lingkungan yang baik untuk perkembangan bakteri-bakteri penyebab penyakit (Pramudiyani \& Prameswari, 2011). Hasil penelitian mendapatkan sebanyak $4,5 \%$ rumah tidak ada ventilasi, dan $52,25 \%$ memiliki ventilasi yang luasnya kurang dari $10 \%$ luas lantai.

Lubang asap dapur berfungsi sebagai keluarnya asap pembakaran, sehingga tidak mencemari udara dalam rumah. Rumah yang mempunyai sedikit ventilasi berupa lubang angin maupun jendela akan meningkatkan jumlah bibit penyakit (Wulandari, Nurjazuli, \& Adi, 2015). Berdasarkan hasil penelitian, diketahui bahwa $19,45 \%$ rumah tinggal tidak memiliki lubang asap dapur, dan $52,01 \%$ telah memiliki namun berukuran kurang dari $10 \%$ luas lantai. Keberadaan lubang asap dapur sangat penting karena asap pembakaran dapat berdampak terhadap kesehatan penghuni di dalam rumah. Asap hasil pembakaran dengan konsentrasi tinggi dapat mengakibatkan rusaknya mekanisme pertahanan paru sehingga akan mempermudah timbulnya penyakit ISPA (Mei Ahyanti \& Duarsa, 2013).

Sebagian besar masyarakat memiliki lubang asap dapur yang belum memenuhi syarat kesehatan, diduga disebabkan oleh kurangnya pengetahuan dan pemahaman masyarakat mengenai lubang asap dapur. Menurut Christiyani (2019), belum tersedianya komponen fisik rumah atau ditemukan fisik rumah dalam kondisi buruk, dikarenakan rendahnya pemahaman responden akan pentingnya pengadaan fisik rumah sehat. Peningkatan pengetahuan dan pemahaman masyarakat dapat dilakukan melalui kegiatan edukasi berupa penyuluhan (Sidiq, 2018).

\section{Sarana Sanitasi}

Berdasarkan hasil penilaian didapatkan sebanyak $34 \%$ rumah memiliki komponen sarana sanitasi yang tidak memenuhi syarat kesehatan. Sarana sanitasi yang tidak memenuhi syarat kesehatan adalah SPAL, sarana pembuangan sampah, serta terdapatnya vektor dan binatang pengganggu (tikus). Air limbah atau air buangan adalah sisa air yang dibuang dari rumah tangga yang pada umumnya mengandung bahanbahan atau zat yang dapat membahayakan bagi kesehatan manusia serta mengganggu lingkungan hidup (Notoatmodjo, 2014). Saluran air limbah rumah tangga berfungsi untuk menyalurkan air limbah sisa mandi, mencuci, dan aktivitas rumah tangga lainnya dari dalam ke luar rumah.

Hasil penelitian mendapatkan hampir separuh rumah $(48,31 \%)$ mengalirkan limbahnya dengan saluran terbuka, bahkan tidak memiliki SPAL (1,37\%). Hasil ini menunjukkan masih rendahnya pengetahuan masyarakat tentang 
penanganan air limbah yang memenuhi syarat kesehatan. SPAL yang tidak memenuhi syarat akan menimbulkan bau, mengganggu estetika dan dapat menjadi tempat perindukan vektor. Air limbah mengandung mikroorganisme patogen dapat membahayakan kesehatan terutama penyakit-penyakit (Duwila, Trijoko, Lanang, \& Astorina, 2018). SPAL yang baik seharusnya berupa saluran tertutup, kedap air, dan ditampung dalam susur resapan atau dialirkan ke riol (Kementerian Kesehatan RI, 1999). SPAL terbuka dan tidak kedap air dapat mencemari tanah dan sumber air, serta menjadi tempat perindukan vektor.

Sampah erat kaitannya dengan kesehatan masyarakat, karena sampah sebagai sumber mikroorganisme penyebab penyakit dan tempat perindukan vektor dan binatang penggangu. Sebanyak $25,16 \%$ rumah tidak memiliki sarana pembuangan sampah, dan 31,03\% menggunakan tempat sampah tidak kedap air dan tidak tertutup. Sarana pembuangan sampah yang sehat harus memenuhi beberapa persyaratan, yaitu konstruksi kuat dan tidak bocor, memiliki tutup dan mudah dibuka tanpa mengotori tangan dan ukurannya sesuai sehingga mudah diangkut (Chandra, 2006). Sampah yang tidak tertangani mengakibatkan tingginya angka kepadatan vektor penyakit (lalat, kecoa dan nyamuk), pencemaran terhadap udara dan juga air serta rendahnya nilai-nilai etika (Yasin et al., 2018).

Penelitian menemukan sebanyak 10,93\% rumah terdapat jentik nyamuk dan tikus; $41,08 \%$ tidak ada jentik, tetapi ada tikus; $11,01 \%$ ada jentik nyamuk, tetapi tidak ada tikus; dan $36,98 \%$ tidak ada jentik nyamuk dan tidak ada tikus. Tempat sampah yang tidak memenuhi syarat akan menjadi tempat perkembangbiakan vektor dan binatang pengganggu, sehingga insiden penyakit tertentu di masyarakat dapat meningkat (Nugraheni, 2012).

\section{Perilaku Penghuni}

Perilaku penghuni rumah sangat berpengaruh terhadap terciptanya kondisi lingkungan yang sehat, sehingga dapat memberikan rasa aman, terhindar dari bahaya dan gangguan kesehatan. Berdasarkan hasil penelitian mendapatkan sebanyak 30,14\% rumah memiliki perilaku yang tidak sehat, yaitu merokok di dalam rumah dan membuka jendela.

Hasil survei diketahui sebanyak 53,62\% rumah memiliki anggota keluarga yang merokok di dalam rumah. Kebiasaan merokok di dalam rumah sangat berbahaya bagi anggota keluarga lainnya yang tidak merokok (perokok pasif). Perokok pasif mempunyai risiko yang sama dengan perokok aktif karena menghirup kandungan karsinogen dalam asap rokok. Asap rokok yang mengandung zat-zat residu rokok dapat terhirup langsung oleh perokok pasif dan dapat tersebar di lingkungan hingga jarak 10 meter. Asap rokok juga dapat menempel di baju maupun benda seperti gorden yang kemudian dapat dihirup (Matt et al., 2011). Pencemaran udara di rumah terjadi akibat asap rokok apabila terhirup oleh penghuni rumah dapat mengganggu saluran pernapasan dan memicu pneumonia (Sarino \& Ahyanti, 2012; Agungnisa, 2019; Cora et al., 2020; Puteri, 2011).

Kebiasaan membuka jendela setiap hari sangat baik untuk pergantian atau sirkulasi udara di dalam rumah. Jendela dan lubang angin sebaiknya selalu terbuka supaya dapat lebih memberikan kesejukan pada ruangan (Notoatmodjo, 2014), sehingga anggota keluarga terhindar dari cemaran asap rokok di dalam rumah (Kartiningrum, 2013). Kebiasaan membuka jendela setiap hari juga merupakan salah satu upaya pencegahan terhadap penyakit infeksi pernafasan, karena adanya sirkulasi udara dan masuknya sinar matahari. Perilaku tidak membuka setiap hari dapat meningkatkan risiko penularan penyakit karena ruangan menjadi lembap, sirkulasi udara tidak lancar, dan tidak ada sinar matahari yang masuk untuk mampu membunuh kuman-kuman penyakit (Nuraini, 2015).

Diperlukan upaya perbaikan perilaku kesehatan masyarakat dengan cara meningkatkan pengetahuan, melalui penyuluhan langsung maupun media, seperti leaflet dan video. Menurut Syukaisih, Alhidayati, Rasyid, \& Rofiqoh (2018), penyuluhan melalui leaflet dan video lebih efektif untuk meningkatkan pengetahuan dan sikap masyarakat. 


\section{SIMPULAN}

Hasil penelitian mendapatkan bahwa komponen fisik rumah (30,06\%), komponen sarana sanitasi $(33,84 \%)$, dan perilaku penghuni $(30,14 \%)$ belum memenuhi syarat kesehatan. Komponen fisik rumah yang tidak memenuhi syarat terutama langit-langit, ventilasi dan lubang asap dapur; sarana sanitasi meliputi pengelolaan limbah rumah tangga dan vektor; dan komponen perilaku adalah kebiasaan merokok di dalam rumah dan membuka jendela. Kondisi ini akan memberikan risiko terhadap peningkatan kasus penyakit berbasis lingkungan, terutama penyakit-penyakit infeksi pernafasan. Diperlukan upaya peningkatan pengetahuan agar terjadi perubahan perilaku kesehatan masyarakat, baik melalui penyuluhan langsung maupun media.

\section{DAFTAR PUSTAKA}

Agungnisa, A. (2019). Physical Sanitation of the House that Influence the Incidence of ARI in Children under Five in Kalianget Timur Village. Jurnal Kesehatan Lingkungan, 11(1), 1. https://doi.org/10.20473/jkl.v11i1.2019.1-9

Ahyanti, May, Rosita, Y., \& Yushananta, P. (2020). Utilisation of the family latrine post declaration ODF. International Journal of Innovation, Creativity and Change, 13(2), 192-204.

Ahyanti, Mei, \& Duarsa, A. (2013). Hubungan merokok dengan kejadian ispa pada mahasiswa politeknik kesehatan kementerian kesehatan tanjungkarang. Jurnal Kesehatan Masyarakat, $7(2), 47-53$.

Chandra, B. (2006). Pengantar Kesehatan Lingkungan (Edisi 1). Jakarta: Jakarta: Buku Kedokteran EGC.

Christiyani, B. R. (2019). Analisis Kondisi Rumah Berdasarkan Tingkat Pemahaman Rumah Sehat di Kelurahan Rowosari Kecamatan Tembalang Kota Semarang. Evaluasi Pengelolaan Limbah Padat Di RSUD Hj. Anna Lasmanah Banjarnegara, 18(3), 31-37. https://doi.org/10.14710/mkmi.18.3.\%p

Cora, N. A., B, M., \& Adam, A. (2020). Kejadian ISPA pada Balita (Studi Analitik Di UPTD Puskesmas Bontomatene Dan Kelurahan Batangmata Kecamatan Bontomatene Kepulauan Selayar). Jurnal Sulolipu: Media Komunikasi Sivitas Akademika Dan Masyaraka, 20(1), 51.

Dinas Kesehatan Kabupaten Pesawaran. (2017).
Profil Kesehatan Kabupaten Pesawaran Tahun 2016. Gedong Tataan: Dinas Kesehatan Kabupaten Pesawaran.

Duwila, F., Trijoko, Lanang, H., \& Astorina, N. (2018). Pemetaan Sanitasi Dasar Dengan Penyakit Diare Pada Masyarakat Desa Pesisir Kecamatan Mangoli Timur Kabupaten Kepulauan Sula Provinsi Maluku Utara Tahun 2018. Jurnal Kesehatan Masyarakat (e-Journal), 6(6), 119-127.

Eliana, \& Sumiati, S. (2016). Kesehatan Masyarakat (Cetakan 1). Jakarta: Pusdik SDM Kesehatan Kemenkes RI, Jakarta.

Kartiningrum, E. D. (2013). Kondisi Rumah Sehat Desa Gayaman Kecamatan Mojoanyar Kabupaten Mojokerto. Hospital Majapahit, 5(2), 19-46.

Kementerian Kesehatan RI. Kepmenkes RI Nomor 829/MEKES/SK/VII/1999 Tentang Persyaratan Rumah Sehat., (1999).

Kementerian Kesehatan RI. (2007). Pedoman Teknis Penilaian Rumah Sehat. Jakarta: Ditjen PPM dan PLP.

Mahendra, I. G. A. P., \& Farapti, F. (2018). Relationship between Household Physical Condition with The Incedence of ARI on Todler at Surabaya. Jurnal Berkala Epidemiologi, 6(3), 227. https://doi.org/10.20473/jbe.v6i32018.227235

Matt, G. E., Quintana, P. J. E., Destaillats, H., Gundel, L. A., Sleiman, M., Singer, B. C., ... Hovell, M. F. (2011). Thirdhand tobacco smoke: Emerging evidence and arguments for a multidisciplinary research agenda. Environmental Health Perspectives, 119(9), 1218-1226. https://doi.org/10.1289/ehp.1103500

Notoatmodjo, S. (2014). Kesehatan Masyrakat Ilmu \& Seni (Edisi Revi). Jakarta: PT. Rineka Cipta.

Nugraheni, D. (2012). Hubungan Kondisi Fasilitas Sanitasi Dasar Dan Personal Hygiene Dengan Kejadian Diare Di Kecamatan Semarang Utara Kota Semarang. Jurnal Kesehatan Masyarakat.

Nuraini, A. (2015). Hubungan Karakteristik Lingkungan Fisik Rumah Dan Perilaku Dengan Kejadian Tb Paru Di Wilayah Kerja Puskesmas Bobotsari Kabupaten Purbalingga. Jurnal Kesehatan Masyarakat (e-Journal), 3(1), 482491.

Pramudiyani, N. A., \& Prameswari, G. N. (2011). Hubungan Antara Sanitasi Rumah Dan Perilaku Dengan Kejadian Pneumonia Balita. KESMAS Jurnal Kesehatan Masyarakat, 6(2), 71-78. https://doi.org/10.15294/kemas.v6i2.1755 
Puteri, A. D. (2011). Analisis Faktor Yang Berhubungan Dengan Kondisi Rumah Sehat Di Desa Bandur Picak Kecamatan Koto Kampar Hulu Tahun 2017. Jurnal Kesehatan Masyarakat, 37(ISSN 2623-1581), 28-41.

Sarino, \& Ahyanti, M. (2012). Perilaku merokok pada siswa smp. Jurnal Keperawatan, VIII(2), 148-155.

Sidiq, R. (2018). Efektivitas penyuluhan kesehatan dalam meningkatkan pengetahuan kader posyandu tentang pencegahan pneumonia pada balita. AcTion: Aceh Nutrition Journal, 3(1), 22. https://doi.org/10.30867/action.v3i1.92

Suwita, K., Syafri, M., \& Fahri, S. (2019). Analisis Determinan Rumah Sehat Dalam Mendukung Pembangunan Berwawasan Lingkungan Di Kelurahan Kebun Handil Kota Jambi Suwita, Muhammad Syafri dan Sukmal Fahri. Jurnal Pembangunan Berkelanjutan, 2(1), 60-73.

Syahidi, M. H., Gayatri, D., \& Bantas, K. (2016). Faktor-faktor yang Mempengaruhi Kejadian Infeksi Saluran Pernapasan Akut (ISPA) pada Anak Berumur 12-59 Bulan di Puskesmas Kelurahan Tebet Barat, Kecamatan Tebet, Jakarta Selatan, Tahun 2013. Jurnal Epidemiologi Kesehatan Indonesia, 1(1), 23-27. https://doi.org/10.7454/epidkes.v1i1.1313

Syukaisih, Alhidayati, Rasyid, Z., \& Rofiqoh, N. (2018). Efektivitas Promosi Kesehatan Dengan Media Leaflet dan Video Terhadap Pengetahuan dan Sikap MAsyarakat miskin tentang Merokok. Jurnal Penelitian Kesehatan Suara Forikes, 9(4),
248-257.

Widiastuti, A. (2019). Pengelolaan Sanitasi Lingkungan Dalam Pembangunan Daerah Di Kota Serang. Jurnal Ekonomi-Qu, 9(2), 178-199.

Wulandari, A. A., Nurjazuli, \& Adi, M. S. (2015). Faktor Risiko dan potensi Penularan Tuberculosis Paru di Kabupaten kendal, Jawa Tengah. Jurnal Kesehatan Lingkungan Indonesia, 14(1), 382-386. https://doi.org/10.1299/kikaic.57.382

Yasin, Z., Mumpuningtyas, E. D., \& Faizin, F. (2018). Faktor Lingkungan yang berhubungan dengan kejadian Diare pada balita di Puskesmas Batang - Bantang Kabupaten Sumenep. Jurnal Ilmu Kesehatan, 3(1), 39-46.

Yushananta, P., Ahyanti, M., \& Hasan, A. (2018). Community Based Total Sanitation in Muara Putih Village, Natar District, Pesawaran Regency. Sakai Sambayan: Journal of of Community Service, 2(2), 76. https://doi.org/10.23960/jss.v2i2.79

Yushananta, P., Setiawan, A., \& Tugiyono, T. (2020). Variasi Iklim dan Dinamika Kasus DBD di Indonesia: Systematic Review. Jurnal Kesehatan, 11(2), 294. https://doi.org/10.26630/jk.v11i2.1696

Yushananta, P., \& Usman, S. (2018). The Incidence of Diarrhea in Babies Affected through the Cleanliness of Eating Utensils and Hands. Journal of Medical Science And Clinical Research, 6(9). https://doi.org/10.18535/jmscr/v6i9.137 